\title{
An Epidemic of Keratoconjunctivitis Due to Adenovirus Type 37
}

\author{
S P HARDING, ${ }^{1} \mathrm{~K}$ J MUTTON,${ }^{2}$ HGAM van der AVOORT ${ }^{3}$ and A G WERMENBOL 3 \\ Liverpool, England and Bilthoven, Netherlands
}

\begin{abstract}
Summary
An epidemic of keratoconjunctivitis due to adenovirus type 37 in Liverpool in 1984 is reported. Initially serum neutralisation suggested that isolates were type 10 but further neutralisation studies supported by DNA restriction enzyme analysis showed that they were type 37 . Clinical and epidemiological features of this cause of epidemic keratoconjunctivitis, recently recognised in the United Kingdom, are presented and the implications for the laboratory investigation discussed.
\end{abstract}

de Jong and co-workers ${ }^{1,2}$ first described adenovirus type 37 (Ad-37) keratoconjunctivitis in 1978 in the Netherlands and went on to present details of its identification and characterisation in $1981 . .^{3,4} \mathrm{Ad}-37$ as a cause of epidemic keratoconjunctivitis $(E K C)$ has, we believe, not been reported in the United Kingdom. Published cases worldwide have been mainly sporadic, ${ }^{3-10}$ with three cases from the United Kingdom. ${ }^{3}$ An outbreak which occurred in an ophthalmologist's office in the United States of America was reported in $1983^{11}$ and a recently published survey of EKC in northern Japan revealed a high incidence of Ad-37 between the years 1982 and 1984.12 The serotype has been isolated in samples from pharynx, intestine, cervix and urethra as well as the eye and isolation from multiple sites in the same individual has been reported. ${ }^{4,13}$

We report an epidemic of adenoviral keratoconjunctivitis that occurred in Liverpool in the latter part of 1984 . It was initially reported as being due to adenovirus type $10^{14}$ but later laboratory investigation revealed it to be type 37 , a newly recognised cause of $\mathrm{EKC}$ in the United Kingdom.

\section{Patients and Methods}

Virology records at the Public Health Laboratory, Fazakerley were analysed for the period coinciding with an outbreak of $\mathrm{EKC}$ at St Pauls Eye Hospital, Liverpool in the autumn and winter of 1984 . Case records of all patients in whom adenovirus had been isolated from conjunctival swabs were sought and details collected.

\section{Serum neutralisation}

Virus identification at the Public Health Laboratory has been by serum neutralisation. Virus raised in tissue culture is mixed with pooled and specific antisera from the Central Public Health Laboratory, Colindale. The mixture is added to tissue culture tubes and observed for inhibition of cytopathic effect.

Aware of crossreactivity between Ad 10 and other types not represented by antisera

Correspondence to: S. P. Harding MB FRCS, Lecturer in Ophthalmology, Honorary Senior Registrar, St Pauls Eye Hospital, Old Hall St, Liverpool L3 9BP

${ }^{1}$ Lecturer in Ophthalmology, St Pauls Eye Hospital, Liverpool. ${ }^{2}$ Consultant Virologist, Public Health Laboratory, Fazakerley Hospital, Liverpool. ${ }^{3}$ Biochemist, Laboratory of Virology, Rijksinstituut voor Volksgezondheid en Milieuhygiene, Bilthoven, Netherlands. ${ }^{3}$ Rijskinstituut voor Volksgezondheid en Milieuhygiene, Bilthoven, Netherlands. 
supplied in the United Kingdom, we sent a selection of isolates initially classified as Ad10 to the Rijksinstituut voor Volksgezondheid en Milieu-hygiene, Bilthoven, Netherlands for investigation by further serum neutralisation and DNA restriction enzyme analysis.

\section{DNA restriction enzyme analysis}

Strains were transported in tissue culture fluid. Viral DNA was extracted from infected human diploid fibroblast cells (strain Gabi) by alkaline lysis in the presence of sodium dodecylsulphate. DNA from all strains was characterised by analysis with ten restriction enzymes (Bam HI, Bgl I, Bgl II, Bst III, Hind III, Kpn I, EcoRI, Sac I, Sma I, Xho I) and classified into DNA variants by a previously described method. ${ }^{15}$

\section{Results}

Between August and December 1984 adenovirus isolates were identified from 53 patients presenting to St Paul's Eye Hospital with follicular conjunctivitis. Twenty-four of these were initially classified as Ad-10. During the five month period other adenovirus strains were identified from 13 patients: three Ad-3, four Ad-4, one Ad-5, four Ad-7 and one Ad-8.

Nineteen isolates were sent to the Netherlands for further serum neutralisation testing and DNA restriction enzyme analysis and all were reclassified as Ad-37. Case sheets were traced for 18 of these patients and were studied.

Follicles were present in $\mathbf{1 6}$ of the $\mathbf{1 8}$ cases $(89 \%)$, ten $(56 \%)$ were unilateral and a preauricular node was palpable in nine $(50 \%)$. Nine $(50 \%)$ had corneal involvement at various stages in the progression from punctate keratitis to subepithelial opacities typically seen in EKC. Two cases were haemorrhagic with one of these also showing pseudomembranes, keratitis and anterior uveitis. Symptom duration at presentation ranged from 1 to 10 days with a mean of 4.8 days. Eleven patients were male and eight were female. Age range was $10-64$ years with a mean of 28.6 years.

DNA characterisation showed that all strains were DNA variant D3 except one that was variant D1.16 The deviant strain occurred in a 10 year old boy who presented early in the epidemic. Apart from his young age the clinical features were similar to the other patients. Six cases were presumed to be hospital acquired in that they had attended between 7 and 14 days prior to onset of symptoms for treatment of another condition. The first four proven cases in the epidemic were acquired in the community with one of these having developed two days after the patient had returned from Thailand: he then presented eight days after the onset of his symptoms. Five weeks after the first patient presented, one of the nurses working in the Accident and Emergency Department developed keratoconjunctivitis and was sent off work for three weeks: she was later shown to have had Ad-37. Presumably she was a factor in the subsequent dissemination of the outbreak although one hospital acquired case did occur before she became symptomatic.

\section{Discussion}

The signs and clinical course of cases seen in the Liverpool epidemic of Ad-37 are consistent with previous reports of clinical involvement by this strain. ${ }^{2,11,12}$ Haemorrhagic conjunctivitis has been documented in 9 cases including our two ${ }^{9,12}$ but not secondary anterior uveitis. The clinical features of Ad37 would appear to be typical of EKC caused by other strains. ${ }^{17,18}$ Classically the strain responsible for EKC has been Ad-8 ${ }^{17,19}$ and more recently Ad-19;20,21 we encountered a large outbreak of type $8 \mathrm{EKC}$ in Liverpool in 1982. ${ }^{14,22}$ Sporadic cases and a few smaller outbreaks have been associated with types 2 , $3,4,7,9,11,14,16,21$ and 29.2,14,15,21-23

The case for Ad-10 being a cause of EKC is weak. The outbreak of Ad-10 EKC in London reported by Darougar et al in $1976^{24}$ was typed by serum neutralisation but in view of the cross reactivity to antisera between types 10,19 and 37 it is possible that this outbreak was in fact due to Ad-37. Tullo and Higgins in Bristol in 1978 reported an outbreak of EKC due to a strain intermediate between Ad-10 and Ad-19 again identified by serum neutralisation. ${ }^{25}$ It was later shown in the Netherlands to be due to Ad-37. Certainly Ad-10 was a rare cause of keratocon- 
junctivitis in the WHO worldwide report in 1983 which included statistics from over 25,000 cases. $^{26}$ In our series not one strain initially identified as Ad-10 was confirmed as such by later investigation.

The situation may be similar with a number of the previously reported Ad-19 epidemics. Four recent studies, one each from Australia ${ }^{7}$ and the $\mathrm{USA}^{5}$ and two from Japan $^{10,12}$ have shown that many isolates initially typed as Ad-19 have in fact been Ad37.

Laboratory investigation of adenovirus isolates in the United Kingdom is usually performed by serum neutralisation against first pooled and then specific antisera. For the classical types this method is satisfactory and relatively inexpensive but unfortunately antisera against Ad-19 and Ad-37 are not readily available. DNA restriction enzyme analysis of isolates is more accurate but is expensive and so has tended to be practised only in research institutes. We feel that supplies of Ad-19 and 37 antisera should be widely available in the United Kingdom and that confirmation by DNA restriction analysis should be more accessible. Meanwhile we would emphasise that when serum neutralisation initially types a virus from the eye as Ad-10 it should be assumed to be Ad-37 pending further investigation.

Early recognition of epidemics is essential so that steps can be taken to minimise their extent particularly in a hospital such as in Liverpool where there is a rapid change-over of staff attending a large number of patients. Infected patients are usually members of the working population and so their fïnancial loss must be added to the considerable morbidity together with the marked disruption to local businesses caused when large numbers of staff are involved.

Another feature of the epidemiology of Ad-37 is its reported association with veneral diseases. ${ }^{2,12}$ It would be interesting to know the likelihood of detecting Ad-37 in cases of genital infection. However it would be difficult to justify routine virology on cervical and urethral swabs in view of findings by Schaap et al of only 4 cases amongst 1477 samples collected from prostitutes with cervicitis living in Rotterdam. Similarly we iso- lated no adenoviruses from over 140 cervical swabs sent for chlamydial culture.

Because of the previously. sporadic nature of Ad-37 isolates the suggestion has been made that the strain is less pathogenic than others. ${ }^{3}$ Our experience and that of Aoki et $a l^{12}$ in Japan suggests however that Ad-37 ranks alongside Ad-8 and 19 as a major cause of EKC. Indeed, as Kemp et $a l^{5}$ have found to be the case in the United States of America, with the changing pattern of adenovirus isolates from EKC it is likely that Ad-37 will shortly become the most important cause in the United Kingdom.

We are indebted to Dr JC de Jong for his help and advice in preparing the manuscript and to Mr F Lyons and Mrs B Wylie for laboratory assistance.

\section{References}

${ }^{1}$ de Jong JC, Schaap GJP, Muzerie CJ, Wermenbol AG. Keratoconjunctivitis due to a new adenovirus. Abstracts of the 4th International Congress of Virology Wageningen: PUDOC $1978 ; 141$.

2 Schaap GJP, de Jong JC, van Bijsterveld OP, Beekhuis WH. A new intermediate adenovirus type causing conjunctivitis. Arch Ophthalmol 1979; 97, 2336-38.

3 de Jong JC, Wigand R, Wadell G, et al. Adenovirus 37: identification and characterisation of a medically important new adenovirus type of subgroup D. J Med Virol 1981; 7: 105-18.

${ }^{4}$ Wadell G, Sundell G, de Jong JC. Characterisation of a new adenovirus genome type associated with keratoconjunctivitis and genital infection by SDS-polacrylamide gel electrophoresis of virion polypeptides and DNA restriction. J Med Virol 1981; 7: 119-25.

5 Kemp MC, Hierholzer JC, Cabradilla CP, Obijeski JF. The changing aetiology of epidemic keratoconjunctivitis: antigenic and restriction enzyme analysis of adenovirus types 19 and 37 isolated over a 10 year period. $J$ Infect Dis 1983; 148: 24-33.

6. Hammond GW, Mauthe G, Joshua J, Hannon CK. Examination of uncommon clinical isolates of human adenoviruses by restriction endonuclease analysis. J Clin Microbiol 1985; 21: 611-16.

7. Meng ZD, Kennett ML, Rodger SM, Dickson KE, Anderson BN, Gust ID. Further characterisation of 41 isolates of adenovirus types 19 / 37 by serum neutralisation and DNA restric- 
tion enzyme analysis. J Hyg Camb 1986; 97: 377-83.

${ }^{8}$ Aoki K, Nakazono N, Ishii K, Kato M, Ohtsuka $\mathrm{H}$. [Clinico-epidemiological study of keratoconjunctivitis due to adenovirus type 37 (Ad 37) in Sapporo, Japan.] Nippon Ganka Gakkai Zasshi 1985; 89(2): 294-8.

${ }^{9}$ Higuchi M, Nakazono N, Ishii K, Ohno S, Matsuda $\mathrm{H}$. [Acute haemorrhagic conjunctivitis caused by a subtype of adenovirus type 37.$]$ Nippon Ganka Gakkai Zasshi 1985; 89(5): 692-5.

${ }^{10}$ Higuchi M. [Studies on new adenovirus types of subgenus D causing conjunctivitis - antigenic and restriction endonuclease analysis of adenovirus types 19 and 37.] Hokkaido Igaku Zasshi 1986; 61(3): 437-47.

${ }^{11}$ Keenlyside R-A, Hierholzer JC, d'Angelo LT. Keratoconjunctivitis associated with adenovirus type 37: an extended outbreak in an ophthalmologist's office. J Infect Dis 1983; 174: 191-8.

12 Aoki K, Kawana R, Matsumoto I, Wadell G, de Jong JC. Viral conjunctivitis with special reference to adenovirus type 37 and enterovirus 70 infection. Jap J Ophthalmol 1986; 30: 158-64.

${ }^{13}$ Cevenini R, Donati M, Landini MP, LaPlaca M. Adenovirus associated with an oculogenital infection. Microbiologica 1979; 2: 425-7.

${ }^{14}$ Harding SP, Mallinson H, Smith JLS, Clearkin LG. Adult follicular conjunctivitis and neonatal ophthalmia in Liverpool, 1980 1984. Eye 1987; 1: 512-21.

15 van der Avoort HGAM, Adrian T, Wigand R, Wermenbol AG, Zomerdijk TPL, de Jong JC. Molecular epidemiology of adenovirus type 21 in the Netherlands and the Federal Republic of Germany from 1960 to 1985 . $J$ Clin Microbiol 1986; 24: 1084-8.
${ }^{16}$ Adrian T, de Jong JC, Wermenbol AG, van der Avoort HGAM, Wigand R. Genome type analysis of adenovirus 37 isolates. $J$ Med Virol 1988; (in press).

${ }^{17}$ Darougar S, Grey RHB, Thaker U, McSwiggan DA. Clinical and epidemiological features of adenovirus keratoconjunctivitis in London. Br J Ophthalmol 1983; 67: 1-7.

18 Vastine DW, Burton IW. Adenoviridae. In: Darrell RW, ed. Viral diseases of the eye. Philadelphia: Lea and Febiger. 1984: 131-146.

${ }^{19}$ Dawson CR, Hanna L, Wood TR, Despain R. Adenovirus type 8 keratoconjunctivitis in the United States. III. Epidemiological, clinical and microbiological features. Am J Ophthalmol 1970; 69: 473-80.

${ }^{20}$ Darougar S, Quinlan MP, Gibson JA, Jones BR, McSwiggan DA. Epidemic keratoconjunctivitis and chronic papillary conjunctivitis in London due to adenovirus type $19 . \mathrm{Br} J$ Ophthalmol 1977; 61: 76-85.

${ }^{21}$ Burns RP, Potter MH. Epidemic keratoconjunctivitis due to adenovirus type 19. Am J Ophthalmol 1976; 81: 27.

22 Lipton J, Patterson AP. Epidemic keratoconjunctivitis in Liverpool. J Roy Coll Gen Pract 1984; 34: 519-20.

${ }^{23}$ Darougar S, Pearce R, Gibson JA, McSwiggan DA. Adenovirus type 21 keratoconjunctivitis. Br J Ophthalmol 1978; 63: 836-7.

${ }^{24}$ Darougar S, Walpita P, Thaker U, Viswalingham N, Gardner L, McSwiggan DA. Adenovirus serotyes from ocular infections in London. Br J Ophthalmol 1983; 67: 111-14.

25 Tullo AB, Higgins PG. An outbreak of adenovirus keratoconjunctivitis in Bristol $\mathrm{BrJ}$ Ophthalmol 1979; 63: 621-6.

${ }^{26}$ Schmitz H, Wigand R, Heinrich W. Worldwide epidemiology of human adenovirus infections. Am J Epidemiol 1983; 117: 455-66. 